DOI: $10.24193 /$ tras.65E.5

Published First Online: 02/25/2022

\section{ARE EMPLOYMENT POLICIES \\ SET UP EFFECTIVELY? \\ CASE STUDY OF SELECTED EU \\ COUNTRIES AND SLOVAKIA*}

\author{
Peter PISÁR \\ Alexandra MERTINKOVÁ
}

Peter PISÁR (corresponding author)

Associate Professor, Department of Finance and Accounting, Faculty of Economics, Matej Bel University, Banská Bystrica, Slovakia

Tel.: 0042-1-905-272.165

E-mail: peter.pisar@umb.sk

\section{Alexandra MERTINKOVÁ}

PhD candidate, Department of Finance and Accounting, Faculty of Economics, Matej Bel University, Banská Bystrica, Slovakia E-mail: amertinkova@umb.sk lic expenditure and how it is provided according to specific support programs. The results suggest that countries such as Austria, Sweden and Germany are examples of the right policy setting (from the allocation of funds to their evaluation). If we evaluate the position of Slovakia, according to the results of the studies, we can say that the most effective tools are in the field of education and therefore the volume of their funding should be increased. Instruments from the Employment incentives section, where Slovakia has the most funds, were found to be effective, but only on the short term, therefore we recommend reassessing the $51.80 \%$ stake in this section. The least effective instruments are in the Direct job creation section, in which Slovakia also invests the lowest amount of funds.

Keywords: active employment policy instruments, allocation of expenditure to active instruments, unemployment insurance, literature review.
* This research was supported by the Slovak Research and Development Agency (APVV), APVV-21-0106 'Innovations of employment support tools and activation of human capital in Slovakia'. We would like to thank the reviewers for their detailed comments and suggestions for the manuscript. 


\section{Introduction}

As passive employment policy began to develop in the 1920s and its importance was found to be crucial, the focus of the policy began to shift to its active components. The importance of active employment measures was first emphasized in the 1993 White Paper when the Luxembourg Summit approved the first set of guidelines aimed at moving towards a more proactive and preventive approach. Active employment policy has become a more flexible instrument of public support, with the European Commission recommending EU countries to allocate their resources in active instruments of employment support in the fight against persistent unemployment.

The aim of the paper is to examine whether the instruments of active employment policy in individual EU countries using the LMP database (Labour Market Policy Database) have been effectively set up, as there is a clear difference in the allocation of public expenditure and how it is provided depending on specific support programs. We will confront the results of our findings with the conclusions of published academic studies, which point to the positive or negative effects of specific employment programs in EU countries together with a detailed examination of their focus in Slovakia. By the synthesis of the knowledge we have acquired, we can talk about a relatively effective or ineffective setting of their policies in a narrower context, as we abstract from other factors ${ }^{1}$.

The contribution and originality of this paper lies in the connection of a detailed view of instruments of active employment policy with the findings of academic research on the effectiveness of specific employment programs.

The article consists of three parts. The first part is a literature review, which emphasizes the current state of research in the field of evaluation of instruments with emphasis on the development of evaluation of education programs. The results are further compared with academic research in evaluating the effectiveness of active employment policy instruments published in European studies. The methodological part defines the goal of the research and the research questions. The results and the discussion combine the knowledge gained regarding the expenditure side of employment policies of EU countries and the findings of published studies. The discussion also generalizes the obtained results and presents proposals for further research in this area for Slovakia and for selected EU countries.

\section{Literature review}

Most evaluation studies focus on a microeconomic evaluation approach, which examines individuals by time, type of program and target group. There are already many good reviews of the microeconomic literature in academia (Kluve, 2006; Betcherman, Olivas and Dar 2004; Card, Kluve and Weber, 2010, but they lack a link to the expenditure side of employment policies and an overall capture of policy settings, from its funding to evalu-

1 We examine active employment policy through public spending, abstracting from other areas of employment policy-making such as tax policy, regulatory and legislative measures. 
ation. They are mainly focused only on grouping the results of realized studies for a certain period; an example of such a study in Slovakia is the study of Kucharčíková, Mičiak and Koňušíková (2017).

We notice the largest expansion of European studies on the effectiveness of active employment policy in Sweden. We also see a wide range of studies in Germany (Annex 1). The key literature in the evaluation of public expenditure in the field of active employment policy is attributed to the authors Martin (2014) and Štefánik et al. (2014). Other studies have examined research expenditure on employment policy according to the LMP database (Havran, 2011; Lechner and Wiehler, 2011; Walter, 2013; Kluve, 2006). The studies carried out so far do not identify significant differences in the results of measures within developed or less developed countries; rather, these countries differ in the types of instruments they apply to a greater extent. The differences are also given by the specifics of individual countries captured in the LABREF database (Labour Market Reforms Database), e.g., specific programs for migrants or young people.

In examining the operation of the tools, we encountered many studies that have positive effects on unemployment (especially in the field of education and start-ups). Only a small group of studies report negative effects. For example, a study (Borra $e t$ al., 2012) from Spain captures the negative effects of education programs on the long run, as did Sianesi (2001) from Sweden, and the studies by Bolvig, Jensen and Rosholm (2003) and Rosholm and Skipper (2003). Weber and Hofer (2004) talk about the zero effects of educational activities on the long run. In contrast, the Swedish (Larsson, 2003) and German (Fitzenberger and Speckesser, 2007) studies attribute zero to negative effects to short-term effects, and educational programs are slightly positive in the long run. This may be partly due to the type of training and whether the training is provided by companies (in practice) or whether these educational activities are 'in the classroom'. The scope or type of training also plays an important role.

Several other studies on education are appearing in Slovakia. For example, in a national study by Pisár et al. (2020), which evaluated the contribution to the REPAS + education program (retraining courses) in the Banská Bystrica Region, we observe very low efficiency. The effectiveness of the tool was also addressed in the SAO study (2018), which analyzed only selected districts for the period 2014 to the first half of 2017. The authors van Ours (2001), Boř́k and Caban (2013) and Boř́k et al. (2015) found a positive impact of the training. In contrast, the study by Tiruneh, Štefánik et al. (2014) found a negative effect over 15 months (long term). From the results we can conclude that the field of education as well as incentives to support employment (Havran; 2011; Barošová et al., 2012; Lubyová, Štefánik et al. 2015 and 2016) are key areas of active employment policy in Slovakia.

\section{Methodology and data}

We assess the evaluation of employment policy instruments in the $27 \mathrm{EU}$ countries. Our main research goal is to examine the focus and effectiveness of employment policy instruments in selected EU countries, including Slovakia, based on the LMP database regarding previous academic research. 
Research question 1: What is the structure of employment policy instruments and the volume of allocation of expenditures for their support in EU countries, including Slovakia? We examine the structure and volume of the allocation of employment policy instruments through descriptive statistics and cluster analysis. Cluster analysis is created using a non-hierarchical distribution according to the K-means method. By identifying what instruments countries are investing in and to what extent, we will respond to the first part of the goal, namely the focus of countries on employment policy. The methodology of research question 1 is based on the LMP database ${ }^{2}$ (Eurostat), which is used by authors such as Martin (2014) and Štefanik et al. (2014), but also by EU policy makers.

Research question 2: What is the effectiveness of employment policy instruments in EU countries, including Slovakia, based on published academic studies? The research question uses a synthesis of published academic studies in research to identify the effectiveness of employment policy instruments. The efficiency is redistributed according to the sections of the LMP database. We focus on the results of the studies and the method used. Finally, we evaluate whether existing studies on the effectiveness of the tools are in line with the focus of the given country (comparison with research question 1 ). The reference period is 2017, regarding the development of 2012-2017. The chosen program for the evaluation of statistical data is the SPSS program.

\section{Results}

The first selected characteristic is the expenditures for 2017, which we examine according to the percentage of GDP of the $27 \mathrm{EU}$ countries for each section of the LMP database separately. Table 1 describes the expenditure on tools in the LMP database. If we look at the average value and the standard deviation, we see that the values of EU countries are more dispersed and there are more significant deviations from the average. This fact confirms our reason for research.

The highest average expenditure under active instruments is achieved in section 1 Employment Services with an average value of $0.132 \% \pm 0.119$ p.p. The average values of the other sections gradually decrease, while section 7 achieves an average value of $0.016 \% \pm 0.035$ p.p. Tools from sections 5.6 and 7 achieve their minimum values of zero (maximum values are highest in section $4-0.479 \%$ and in section $1-0.456 \%$ ). Within passive instruments, the average value is at a much higher percentage, namely $0.644 \% \pm 0.519$ p.p. Section 9 is of low significance, as it includes only 12 countries (other values are not available).

2 The instruments of the LMP database are grouped into three main types: LMP services, LMP measures and LMP support, and are further classified into eight detailed categories. Active instruments fall into the first two categories and their division is as follows: labor market services, training, employment incentives, supported employment and rehabilitation, direct job creation and start-up incentives. Passive support is included in the third category and is divided into 2 areas: out-of-work income maintenance and support and early retirement. 
From the point of view of countries, Denmark (almost 2\% of GDP on active measures) and Sweden (1.22\% of GDP) draw the largest amount of funding. Romania is the country with the lowest share of individual measures in the LMP database; the situation is similar in Cyprus. Slovakia is one of the countries with the lowest expenditure on active measures ( $0.22 \%$ of GDP). Only countries such as Romania, Cyprus, Bulgaria, Greece, and Latvia show lower funding.

Table 1: Characteristics of total expenditure on employment policy instruments in \%

\begin{tabular}{|c|c|c|c|c|}
\hline $\begin{array}{c}\text { LMP database sections/ } \\
\text { characteristics }\end{array}$ & $\begin{array}{l}\text { Average } \\
\text { values }\end{array}$ & MIN & MAX & $\begin{array}{c}\text { Total } \\
\text { expenditure }\end{array}$ \\
\hline \multicolumn{5}{|c|}{ A. LMP services } \\
\hline 1. Labor market services & $0.132 \pm 0.119$ & 0.05 (Greece) & 0.456 (Denmark) & 3,575 \\
\hline \multicolumn{5}{|c|}{ B. LMP measures } \\
\hline 2. Training & $0.119 \pm 0.122$ & 0.003 (Romania) & 0.444 (Austria) & 3,238 \\
\hline 4. Employment incentives & $0.106 \pm 0.109$ & 0.02 (Bulgaria) & 0.479 (Sweden) & 2,877 \\
\hline $\begin{array}{l}\text { 5. Supported employment } \\
\text { and rehabilitation }\end{array}$ & $0.096 \pm 0.185$ & 0 (Bulgaria. Greece. Romania) & 0.909 (Denmark) & 2,61 \\
\hline 6. Direct job creation & $0.069 \pm 0.131$ & 0 (Estonia. Sweden) & 0.621 (Hungary) & 1,886 \\
\hline 7. Start-up incentives & $0.016 \pm 0.035$ & $\begin{array}{l}0 \text { (Bulgaria. Cyprus. Ireland. } \\
\text { Luxembourg. Romania) }\end{array}$ & 0.132 (Spain) & 0,446 \\
\hline \multicolumn{5}{|c|}{ C. LMP supports } \\
\hline $\begin{array}{l}\text { 8. Out-of-work income } \\
\text { maintenance and support }\end{array}$ & $0.644 \pm 0.519$ & 0.046 (Romania) & 1.954 (France) & 17,393 \\
\hline $\begin{array}{l}\text { 9. Early retirement } \\
\text { (only } 12 \text { countries) }\end{array}$ & $0.118 \pm 0.127$ & 0 (France) & 0.364 (Portugal) & 1,423 \\
\hline
\end{tabular}

Source: Authors' own work in accordance with LMP database, 2020

The development is relatively similar for the whole monitored period (2012-2017) according to the LMP database. This means that in the given years the countries did not fundamentally change their strategies and the analysis of 2017 is, from our point of view, not distorted by one-off changes or significant deviations. We record slight fluctuations in values in Ireland, Hungary, Belgium and Cyprus.

However, in addition to the above statements, it is interesting to monitor the link between expenditure and the number of measures. The data in Table 2 marked in yellow indicate the highest number of measures in the section, but the largest share of funds was recorded in another section. Green means that the largest number of measures is in line with the largest share of expenditure.

The results are surprising for Hungary, which invests $72.55 \%$ of expenditure $(0.621 \%$ of GDP) in one measure in section 6 called Közfoglalkoztatás. The primary purpose of the measure is the reintegration of currently inactive and unemployed groups into the labor market. Greece also invests most of its funding in one measure, which is to support employment through welfare schemes. The target group is registered as unemployed and 
affected by the economic crisis. The volume of Greek funding for this measure is $0.118 \%$ of GDP out of a total of $0.177 \%$ of GDP. Slovakia invests approximately $46 \%$ of its funds for active measures in 8 instruments in section 4 .

Table 2: Number of instruments and their relation to the largest expenditure shares

\begin{tabular}{lccccccc}
\hline Country & LMP section & Section 1 & Section 2 & Section 4 & Section 5 & Section 6 & Section 7 \\
\hline Austria & 9 & $11(36.10 \%)$ & 7 & 3 & 2 & 1 \\
\hline Belgium & $24(36.06 \%)$ & 19 & 20 & 16 & 8 & 4 \\
\hline Bulgaria & 4 & 18 & 14 & 0 & $14(41.30 \%)$ & 2 \\
\hline Cyprus & 3 & 6 & $13(43.93 \%)$ & 1 & 0 & 1 \\
\hline Czech Republic & $3(36.98 \%)$ & 2 & 6 & 2 & 1 & 3 \\
\hline Germany & $20(58.74 \%)$ & 23 & 6 & 7 & 4 & 4 \\
\hline Denmark & 2 & 2 & 5 & $6(31.87 \%)$ & 0 & 0 \\
\hline Estonia & 12 & 7 & $14(36.21 \%)$ & 3 & 2 & 4 \\
\hline Greece & 7 & 4 & 26 & 2 & $1(56.50 \%)$ & 4 \\
\hline Spain & $15(22.35 \%)$ & 12 & 12 & 3 & 3 & 8 \\
\hline Finland & 12 & $6(35.79 \%)$ & 2 & 4 & 3 & 2 \\
\hline France & $17(26.92 \%)$ & 17 & 10 & 3 & 3 & 3 \\
\hline Croatia & 17 & $5(33.51 \%)$ & 6 & 1 & 1 & 3 \\
\hline Hungary & 3 & 2 & 7 & 0 & $1(72.55 \%)$ & 1 \\
\hline Ireland & 7 & 12 & 2 & 2 & $3(36.19 \%)$ & 1 \\
\hline Lithuania & 7 & 4 & $7(40 \%)$ & 2 & 1 & 1 \\
\hline Luxembourg & 5 & 7 & $7(35.33 \%)$ & 6 & 5 & 1 \\
\hline Latvia & $15(29.26 \%)$ & 5 & 8 & 1 & 2 & 2 \\
\hline Malta & $5(59.75 \%)$ & 6 & 10 & 3 & 2 & 0 \\
\hline Netherlands & $8(34.43 \%)$ & 5 & 2 & 2 & 0 & 0 \\
\hline Norway & $10(31.99 \%)$ & 2 & 4 & 5 & 0 & 1 \\
\hline Poland & 8 & 11 & 14 & $7(39.14 \%)$ & 3 & 2 \\
\hline Portugal & 4 & 25 & $30(39.65 \%)$ & 4 & 10 & 8 \\
\hline Romania & $6(51.85 \%)$ & 4 & 13 & 0 & 1 & 2 \\
\hline Sweden & 9 & 9 & $14(28.30 \%)$ & 5 & 0 & 4 \\
\hline Slovenia & $8(30.65 \%)$ & 9 & 7 & 1 & 4 & 1 \\
\hline Slovakia & 3 & 3 & $8(45.95 \%)$ & 4 & 1 & 2 \\
\hline & & & & & & \\
\hline
\end{tabular}

Source: Authors' own work in accordance with data from LMP reports of EU countries, 2020

As the literature has already indicated, it is not appropriate to examine employment policy only from the point of view of active instruments, but it is also necessary to consider its passive component, which cannot be strictly separated from active policy.

Therefore, the following figure is focused on the structure of instruments, where we see that, on average, passive instruments predominate over active ones $(56.25 \%)$. The fig- 
ure also shows that 16 countries are still financing passive instruments to a greater extent. Slovakia is one of these countries and of the total resources for employment policy instruments it spends $60 \%$ of its funds on passive instruments (the highest share is in Cyprus). However, we cannot draw any authoritative conclusions from the results, it is only a trend that prevails between countries, as the threshold for the distribution of employment policy instruments is not set and EU countries break down their policies according to individual strategies and needs.

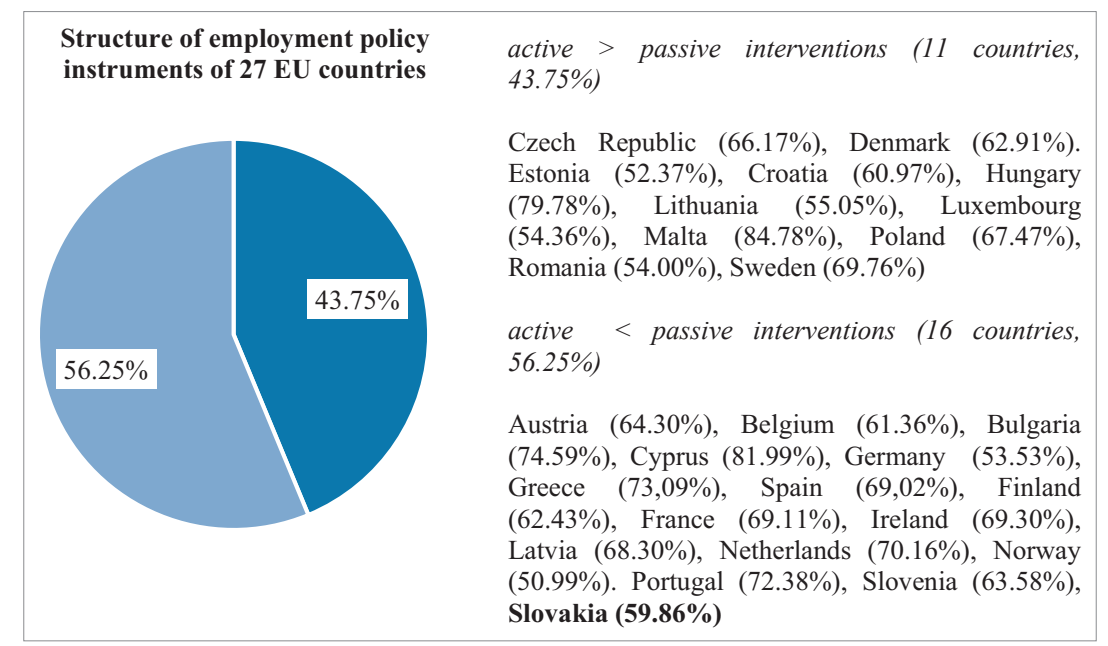

Figure 1: Structure of active and passive employment policy instruments in EU countries

Source: Authors' own work according to Eurostat data, 2020

Considering the aspect of the unemployment rate and the volume of funds spent on active employment policy instruments, we can divide the surveyed countries according to their distribution into 3 groups (Figure 2).

The first group of countries includes the seven (7) countries that have the highest values of total expenditure and the lowest unemployment rate. The second group of countries consists of two (2) countries (Greece and Spain) and their values achieve the highest unemployment rate and the lowest absorption of funds for employment policy instruments. The last group of 18 countries, in which Slovakia is also found, represents countries with an unemployment rate lower than group 2 and at the same time the total expenditure on instruments is lower than in group 1 .

We can say that group 1 therefore consists of the most favorable countries in active policy expenditure with a relatively low unemployment rate. Group 2 forms a contradictory situation (countries with a relatively high unemployment rate) and Group 3 can be called a gray zone, which does not show significant values from both indicators. 


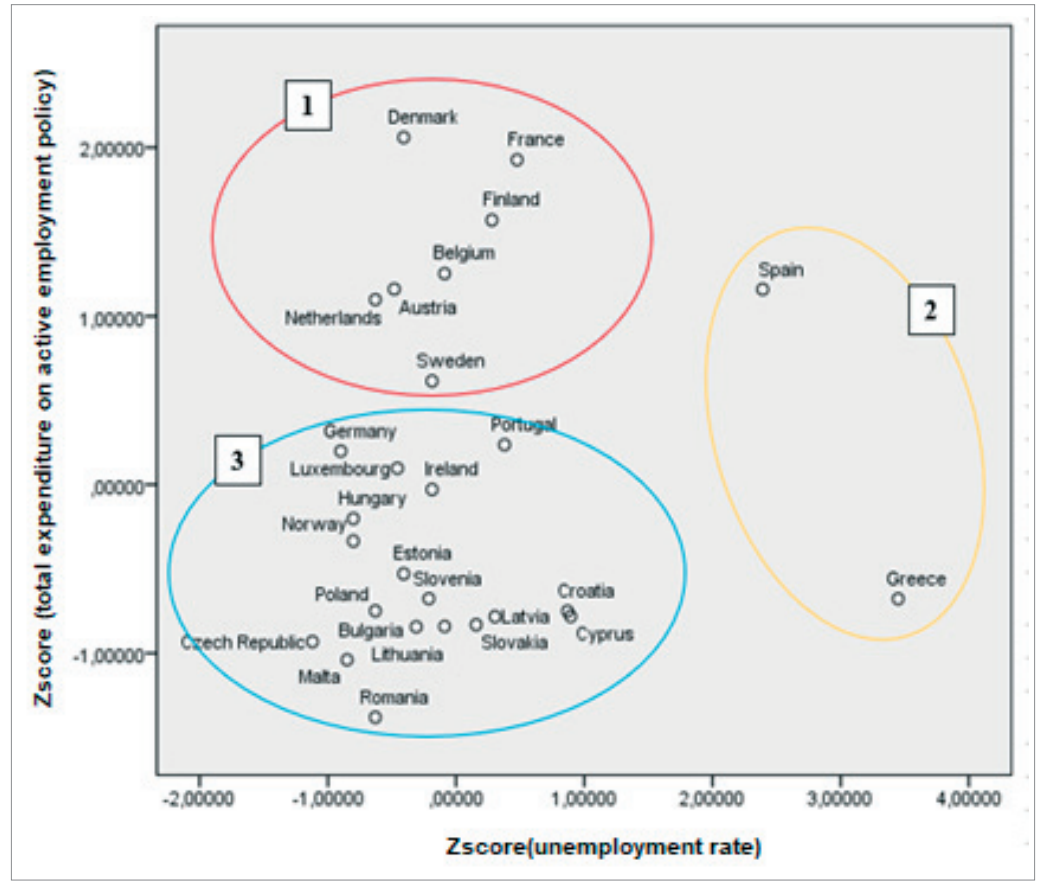

Figure 2: Distribution of EU countries according to selected characteristics

Source: Authors' own work in the SPSS program, 2020

\section{Discussion}

By synthesizing 41 studies in evaluating the effectiveness of active employment policy instruments and examining in detail the focus of individual countries, we can speak of a relatively effective or ineffective setting of policies of individual EU countries (in a narrower context, as we abstract from other factors).

Literature review suggests that Slovakia has the largest number of sources mentioned due to greater attention and overview of authors. Slovakia most often focuses in its research on section 4 of the LMP database, in which it also invests the largest amount of its funds. According to the results of the studies, we can say that Slovakia has the most effective tools in the field of education and should therefore increase the amount of funding, as we suggest in chapter Results (Research question 1). The least effective instruments are from section 6, where Slovakia also invests the lowest volume. These are measures for activation activities, which are a kind of maintainer of recipients of unemployment benefits. According to the qualitative research from the study conducted by Pisár et al. (2020) we can see that support should only be an intermediate step in adapting benefit recipients to the labor market, however, this is not the case. Beneficiaries are cyclical and their chances on the labor market are not increasing. Due to the ongoing discussions, it is necessary to keep the tool, albeit being ineffective. The Rodríguez-Planas study (2010) also pointed 
out in its research in Romania that public employment schemes (activation work) are the only ones that have negative effects (they also examined programs in the field of education, SZC and employment services). A study from Slovenia by Vodopivec (1999) again shows a positive impact within a period of three months. If the period exceeds three months, it is apparent that the support is negligible. At the same time, the study confirmed the fact that the support should only be a kind of bridging period and its duration and repeatability should not be so intense.

An example of the right policy setting (from the allocation of funds to their evaluation) is Austria. Research studies by Weber and Hofer (2004), Winter-Ebmer (2006), Lechner and Whieler (2011) have shown positive effects in the field of education, which is a priority area for their expenditure side of active employment policy. This fact may also be due to a high proportion of NEETs persisting in the country, which forces the country to address the effectiveness of the tools for young people. Another example is Sweden, which, with its focus on section 4, shows the positive effects of the instruments in this section. We rank both countries as those with high expenditures and low unemployment. In addition, Swedish employment policy has a priority focus on its active component, which testifies to the country's maturity.

As part of the implication for employment policies in the Slovak Republic, we recommend considering reducing the number of implemented instruments. The result is a complicated support system that is confusing or too extensive for many entrepreneurs, resulting in, for example, too little interest in some programs. At the same time, low-usage tools are administratively demanding and inefficient. Many measures, which can be combined with each other, also make it very difficult to realistically evaluate the given instruments. We can see that countries with a better tradition of evaluating measures have a lower total number of these measures (Denmark, Hungary, the Netherlands).

The second recommendation is greater diversification of the regional dimension of contributions. According to Pisár et al. (2020) the results show that the measures work differently in individual regions or districts, which is confirmed by several other studies (e.g., Štefánik et al., 2014). At the same time, overall efficiency is very low, so it is very questionable in regions with low unemployment. To verify some of the effects of the measure, it may be appropriate to pilot them in selected districts. This would also allow better collection of qualitative and quantitative data to evaluate the effectiveness of the instruments. Increasing the use of a tool focused on education (section 2 of the LMP database) would also strengthen the employability of members of the Roma, who are often disadvantaged by direct tools (Kureková, 2015).

The most significant effects can be seen in the field of education and training, where we positively evaluate the use of the PSM method (it is an adopted method from the field of health care). However, the question remains as to why there is such a strong need to examine the field of education. We believe that this is partly due to the EU policy makers (Europe 2020 Strategy) and to the long-term effect of the instrument. Tools from other sections of the LMP database are either short-term in nature or their effects are not clear, and there are many financial and non-financial benefits in education. Even in the develop- 
ment of human capital, it is said that education provides the well-being of the nation in the form of positive externalities. If support is captured before entering the labor market, there is a better chance of higher earnings and a better standard of living. Finally, we note that the search for studies is not final, which may skew the results over time.

\section{Conclusion}

Expenditure on active employment policy instruments contributes to the creation and development of employment, but in different ways in different countries. Given that expenditure is a key indicator, the aim of our research was to examine whether active employment policy instruments in individual EU countries using the LMP database were effectively set up, as there is a clear difference in the allocation of public expenditure and the delivery according to specific support programs.

Expenditure analysis shows that there is a difference in the employment policy strategy between countries. On the one hand, there are countries (Denmark, France, Finland, Belgium, Austria, the Netherlands, Sweden) that have relatively high spending on active policy and the lowest unemployment rates. On the other hand, Greece, Cyprus, Croatia, Latvia, and Slovakia are countries with relatively high unemployment rates and their expenditures are significantly lower. The best rated countries are Denmark and Sweden, as their policies are focused on its active part and achieve exemplary results in terms of unemployment rates and financial resources. Denmark invests about 32\% of its expenditure in six active instruments in section 5 . Sweden focuses on section 4 , which is supported by 14 instruments with a $28 \%$ expenditure share and, according to studies (Forslund, Johansson and Lindqvist, 2004; Carling and Larsson, 2005; Andrén and Andrén, 2006; Sianesi, 2001; Larsson, 2003; Carling and Richardson, 2001) are also effective tools. Austria, together with Sweden, are one of the examples of good policy making. Employment policy in the Czech Republic is focused on section 1 (employment services) and invests 37\% of its resources oriented towards aid providers. Research (Potluka et al., 2016; Kopečná, 2016; Potluka et al., 2012; Dvouletý and Hora, 2020) points to the positive impacts of targeted programs, but they are not located in the employment services section. Therefore, we cannot discuss whether the employment policy set in this way also shows an effective setting, but we emphasize that the Czech Republic invests a higher share of funds in active instruments (66.17\%). This means that it seeks to make a stronger effort to support the transition of the unemployed to the labor market than to maintain financial support for the unemployed. In this case, Slovakia is the complete opposite (59.86\% share of passive measures).

If we evaluate the position of Slovakia, the results show that Slovakia is the country with the 6th lowest funding of policy instruments ( $0.22 \%$ of GDP active instruments; $0.55 \%$ of GDP in total). The funding structure of the instruments is $40.14 \%$ (active instruments) to $59.86 \%$ (passive instruments), which does not meet the European guidelines. Furthermore, we can say that Slovakia spends the largest amount of funds on eight (8) instruments aimed at employers in section 4, which evaluates the instruments as effective in the short term. To approach the EU average or the countries with the lowest unemployment rates, 
Slovakia should direct its instruments in the area of public spending from the category of incentives to support employment (section 4) to the area of education support (section 2). Based on the studies carried out, it is questionable to increase the rate of direct job creation (section 6), as the effectiveness of these tools is highly debatable. Based on the cluster analysis, Slovakia most closely resembles the countries of Cyprus, Croatia, and Latvia in terms of these characteristics (total expenditure and unemployment rate).

An example of a tool that would improve the results obtained (low level of education tools in section 2) is the retraining course REPAS +. It is one of the cheapest and therefore relatively effective tools in Slovakia (Pisár et al., 2020). It is a tool that is used across age and educational characteristics, and thus from this point of view the most universal of the examined tools. Its low usability is mainly justified by the low share of courses that improve skills for the future (IT courses) or its ability to use the contribution only once.

The study carried out on the effectiveness of employment policies could be extended to include a passive component, which we cannot strictly separate from active instruments. The results obtained that way would indicate, on one hand, a global view of the effectiveness of employment policy and, on the other hand, which countries tend to integrate jobseekers into the labor market or tend to improve the living situation of the unemployed. It is also possible to focus on a new indicator in European documents, namely the quality index on quality of ALMP (Active Labour Market Policy) implementation.

\section{References:}

1. Andrén, D. and Andrén, T., 'Assessing the Employment Effects of Vocational Training Using a One-factor Model', 2006, Applied Economics, vol. 38, no. 21, pp. 2469-2486.

2. Betcherman, G., Olivas, K. and Dar, A., 'Impacts of Active Labor Market Programs: New Evidence from Evaluations with Particular Attention to Developing and Transition Countries', 2004, Social Protection Discussion Papers and Notes 29142, The World Bank.

3. Barošová, M., Doválová, G., Kešelová, D. and Košta, J., 'Uplatňovanie aktívnych opatrení na trhu práce v kontexte s aplikačnou praxou Európskej únie' (Application of Active Labor Market Measures in the Context of the Application Practice of the European Union), 2012, Záverečná správa VÚ č. 2159 MPSVR SR.

4. Bořík, V. and Caban, M., 'Pilotné hodnotenie dopadov vybraných opatrení aktívnej politiky trhu práce' (Pilot Evaluation of the Impacts of Selected Active Labor Market Policy Measures), 2013, Bratislava: MPSVR, ÚPSVaR.

5. Bořík, V., Duurica, M., Molnárová, M. and Švábová, L., 'The Net Effects of Graduate Work Experience and the Promotion of Self-employment', 2015, Technical Report, [Online] available at https://www.employment.gov.sk/files/slovensky/esf/op-zasi/technical-evaluation-repo rt_final5edit.pdf, accessed on August 21, 2021.

6. Borra, C., Palma, L., González, M.C. and Aguado, L.F., 'Evaluation of an Active Labour Market Programme in a Context of High Unemployment', 2012, Revista Desarrollo y Sociedad, no. 70, pp. 93-115.

7. Bolvig, I., Jensen, P. and Rosholm, M., 'Employment Effects of Active Social Policy', 2003, IZA Discussion Paper, no. 736. 
8. Card, D., Kluve, J. and Weber, A., 'Active Labour Market Policy Evaluations: A Meta-Analysis', 2010, Economic Journal, Royal Economic Society, vol. 120, no. 548, pp. F452-F477.

9. Carling, K. and Larsson, L., 'Does Early Intervention Help the Unemployed Youth?', 2005, Labour Economics, vol. 12, no. 3, pp. 301-319.

10. Carling, K. and Richardson, K., 'The Relative Efficiency of Labor Market Programs: Swedish Experience from the 1990s', 2001, Swedish Office of Labour Market Policy Evaluation, Working Paper, no. 2.

11. Centeno, L., Centeno, M. and Novo, A.A., 'Evaluating the Impact of a Mandatory Job Search Program: Evidence from a Large Longitudinal Data Set', Lisbon, 2005.

12. Cockx, B., Bruno, V.L. and Adel, K., 'Active Labour Market Policies and Job Tenure', 1998, Oxford Economic Papers, vol. 50, no. 4, pp. 685-708.

13. Crépon, B., Ferracci, M. and Fougčre, D., 'Training the Unemployed in France: How Does It Affect Unemployment Duration and Recurrence?', 2007, IZA Discussion Paper, no. 3215.

14. Crépon, B., Dejemeppe, M. and Gurgand, M., 'Counseling the Unemployed: Does It Lower Unemployment Duration and Recurrence?’, 2005, IZA Working Paper, no. 1796.

15. Dvouletý, O. and Hora, O., 'Analýza dopadů programu podpory podnikání pro nezaměstnané v České republice' (Analysis of the Impacts of the Business Support Program for the Unemployed in the Czech Republic), 2020, Politická ekonomie, vol. 68, no. 2, pp. 142-167.

16. European Commission, 'Labour Market Reforms Database, Eurostat Meta Data. LABREF Database', [Online] available at https://webgate.ec.europa.eu/labref/public/, accessed on June 15, 2018a.

17. European Commission, 'Labour Market Policy. Eurostat Meta Data', [Online] available at https://ec.europa.eu/employment_social/employment_analysis/lmp/lmp_esms.htm, accessed on May 24, 2018b.

18. European Commission, 'Total Unemployment Rate. Eurostat Data', [Online] available at https://ec.europa.eu/eurostat/tgm/table.do? tab=table\&init $=1 \&$ language $=$ en $\&$ pcode $=$ tp s00203\&plugin=1, accessed on May 24, 2018c.

19. European Commission, 'Labour Market Policy Statistics: Qualitative Report. Eurostat LMP database', [Online] available at https://ec.europa.eu/social/main.jsp?pager.offset $=25 \& \mathrm{radv}$ SearchKey $=\mathrm{LMP}+\mathrm{Qualitative}+$ report $\&$ mode $=$ advancedSubmit\&catId=1307\&doc_sub mit $=\&$ policyArea $=0 \&$ policyAreaSub=0\&country=0\&year=0, accessed on July 30, 2019.

20. Eurostat, 'LMP Expenditure by Type of Action - Summary Tables', [Online] available at https://webgate.ec.europa.eu/empl/redisstat/databrowser/view/LMP_EXPSUMM/default/ table, accessed on July 29, 2019.

21. Fitzenberger, B. and Speckesser, S., 'Employment Effects of the Provision of Specific Professional Skills and Techniques in Germany', 2007, Empirical Economics, vol. 32, no. 2, pp. 529-573.

22. Forslund, A., Johansson, P. and Lindqvist, L., 'Employment Subsidies - A Fast Lane from Unemployment to Work?', 2004, IFAU Working Paper, no. 18.

23. Girma, S., Görg, H., Strobl, E. and Walsch, F., 'Creating Jobs through Public Subsidies: An Empirical Analysis', 2008, Labour Economics, vol. 15, no. 6, pp. 1179-1199.

24. Havran, P., 'Hodnotenie efektívnosti a účinnosti výdavkov na aktívne politiky trhu práce na Slovensku' (Evaluation of Efficiency and Effectiveness of Expenditures on Active Labor Market Policies in Slovakia), 2011, [Online] available at https:/www.mfsr.sk/sk/financie/institut-fi nancnej-politiky/publikacie-ifp/ekonomicke-analyzy/22-hodnotenie-efektivnosti-ucinnos 
ti-vydavkov-aktivne-politiky-trhu-prace-slovensku-januar-2011.html, accessed on August 21, 2021.

25. Kluve, J., 'The Effectiveness of European Active Labour Market Policy', 2006, IZA Discussion Paper, no. 2018.

26. Kluve, J., Lehmann, H. and Schmidt, C.M., 'Disentangling Treatment Effects of Active Labor Market Policies: The Role of Labor Force Status Sequences', 2005, revised version of IZA Discussion Paper, no. 355.

27. Kopečná, V., 'Counterfactual Impact Evaluation of the Project Internships for Young Job Seekers', 2016, Central European Journal of Public Policy, vol. 10, no. 2, pp. 48-66.

28. Kucharčíková, A., Mičiak, M. and Koňušíková, L'., 'Hodnotenie aktívnej politiky trhu práce' (Evaluation of Active Labour Market Policy), 2017, Journal of Knowledge Society, vol. 1, pp. 22-33.

29. Kureková, M.L., 'Policy Puzzles with Roma Employment in Slovakia', 2015, CELSI, Discussion Paper, no. 34, [Online] available at https://celsi.sk/media/discussion_papers/CELSI_DP_34_. pdf, accessed on August 21, 2021.

30. Larsson, L., 'Evaluation of Swedish Youth Labour Market Programmes', 2003, Journal of Human Resources, vol. 38, no. 4, pp. 891-927.

31. Lechner, M. and Wiehler, S., 'Kids or Courses? Gender Differences in the Effects of Active Labor Market Policies', 2011, Journal of Population Economics, vol. 24, no. 3, pp. 783-812.

32. Leetmaa, R. and Vôrk, A., 'Evaluation of Active Labour Market Programmes in Estonia', Tallin, 2004.

33. Lubyová, M., Štefánik, M., et al., 'Trh práce na Slovensku 2016+' (Labor Market in Slovakia 2016+), 2015, Ekonomický ústav SAV.

34. Lubyová, M., Štefánik, M., et al., 'Trh práce na Slovensku 2017+'(Labor Market in Slovakia 2017+), 2016, Ekonomický ústav SAV.

35. Martin, P.J., 'Activation and Active Labour Market Policies in OECD Countries: Stylized Facts and Evidence on their Effectiveness', 2014, IZA Policy Paper, no. 84.

36. Micklewright, J. and Nagy, G., 'The Effect of Monitoring Unemployment Insurance Recipients on Unemployment Duration: Evidence from a Field Experiment', 2010, Labour Economics, vol. 17 , no. 1 , pp. $180-187$.

37. Pisár, P., Šipikal, M., Úradníček, V., Hiadlovský, V., Huňady, J. and Mertinková, A., 'Štúdia na hodnotenie tvorby a udržania pracovných miest z operačných programov podporovaných zo zdrojov Európskej únie s osobitným dôrazom na jeden z najmenej rozvinutých regiónov (BBSK/ PSK/KSK) podl'a vlastného výberu, ktorý čelí významným problémom s mierou nezamestnanosti' (Study to Assess Job Creation and Retention from Operational Programs Supported by the European Union, with Special Emphasis on One of the Least Developed Regions (BBSK/ PSK/KSK) of Its Choice, Which Faces a Significant Problem with the Unemployment Rate), [Online] available at https://www.employment.gov.sk/files/slovensky/esf/op-ludske-zdroje/ hodnotenie/studia-hodnotenie-prac-miest-mpsvr-sr.pdf, accessed on August 21, 2020.

38. Pirciog, S., Ciuca, V. and Popescu, E.M., 'The Net Impact of Training Measures from Active Labour Market Programs in Romania - Subjective and Objective Evaluation', 2015, Procedia Economics and Finance, vol. 26, pp. 339-344.

39. Potluka, O., Brůha, J., Spacek, M. and Vrbova, L., 'Counterfactual Impact Evaluation on EU Cohesion Policy Interventions in Training in Companies', 2016, Ekonomický časopis, vol. 64, no. 6, pp. 575-595. 
40. Rodriguez-Planas, N. and Benus, J., 'Evaluating Active Labor Market Programs in Romania', 2010, Empirical Economics, vol. 38, no. 1, pp. 65-84.

41. Rosholm, M. and Skipper, L., 'Is Labour Market Training a Curse for the Unemployed? Evidence from a Social Experiment', 2003, Journal of Applied Econometrics, vol. 24, no. 2, pp. 338-365.

42. Sianesi, B., 'Differential Effects of Swedish Active Labour Market Programmes for Unemployed Adults during the 1990s', Institute for Labour Market Policy Evaluation, 2001.

43. Štefánik, M., Lubyová, M., Dovál'ová, G. and Karasová, K., 'Analýza účinkov nástrojov aktívnej politiky trhu práce' (Analysis of the Effects of Active Labor Market Policy Instruments), 2014, Education Center: Ministry of Labor, Social Affairs and Family, [Online] available at https:// www.ia.gov.sk/data/files/np_csd_I/KOZ/Analyza_ucinkov_nastrojov_aktivnej_politiky_ trhu_prace_finalna_verzia.pdf, accessed on August 21, 2021.

44. Tiruneh, M.W., Štefánik, M., et al., 'Trh práce na Slovensku: analýzy a prognózy' (Labor Market in Slovakia: Analyzes and Forecasts), 2014, Ekonomický ústav SAV.

45. Van Ours, J.C., 'Do Active Labor Market Policies Help Unemployed Workers to Find and Keep Regular Jobs?', in Lechner, M. and Pfeiffer, F. (eds.), Econometric Evaluation of Labour Market Policies, Springer, 2001, pp. 125-152.

46. Vodopivec, M., 'Does the Slovenian Public Work Program Increase Participants' Chances to Find a Job?', 1999, Journal of Comparative Economics, vol. 27, no. 1, pp. 113-130.

47. Walsh, K., Kotzeva, M., Dölle, E. and Dorenbos, E., 'Evaluation of the Net Impact of Active Labour Market Programs in Bulgaria', 2001, NEI Labour and Education, [Online] available at https://ec.europa.eu/migrant-integration/library-document/evaluation-net-impact-active-la bour-market-programmes-bulgaria_en, accessed on August 24, 2021.

48. Walter, T., 'Fiscal Cost-Benefit Analyses for Temporary Extra Jobs and Short-Term Training Programs', 2013, ZEW Economic Studies, no. 46.

49. Weber, A. and Hofer, H., 'Employment Effects of Early Interventions on Job Search Programs', 2004, IZA Discussion Paper, no. 1076.

50. Winter-Ebmer, R., 'Coping with a Structural Crisis: Evaluating an Innovative RedundancyRetraining Project', 2006, International Journal of Manpower, vol. 27, no. 8, pp. 700-721. 


\begin{tabular}{|c|c|c|c|c|c|c|c|c|}
\hline 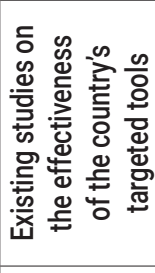 & 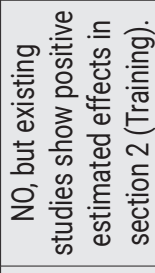 & & 운 & 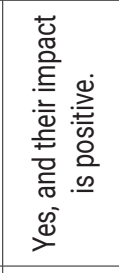 & 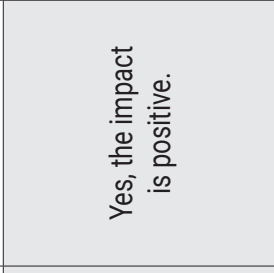 & $\stackrel{\mathscr{\infty}}{\rightleftharpoons}$ & 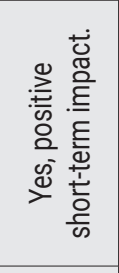 & 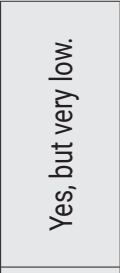 \\
\hline 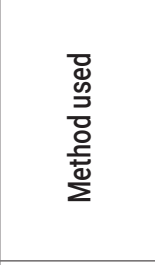 & $\sum_{\infty}$ & 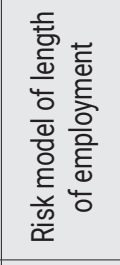 & 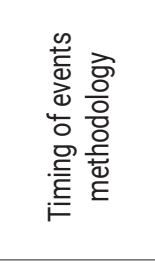 & 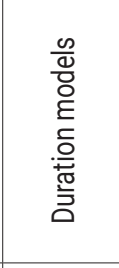 & 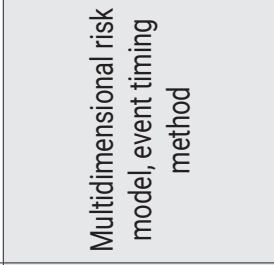 & 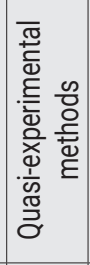 & 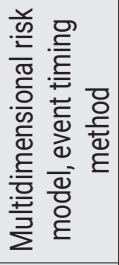 & $\frac{\frac{\pi}{\pi}}{\frac{\pi}{0}}$ \\
\hline 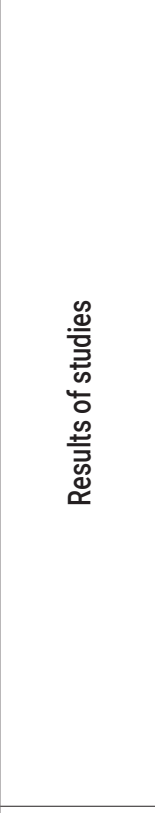 & 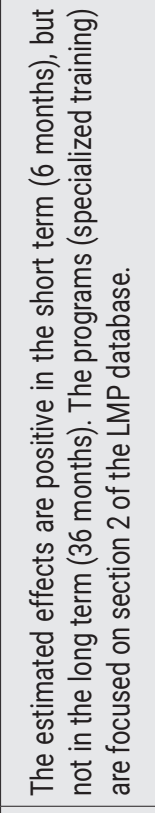 & 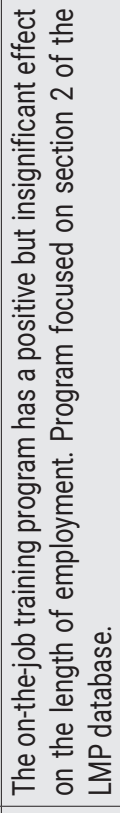 & 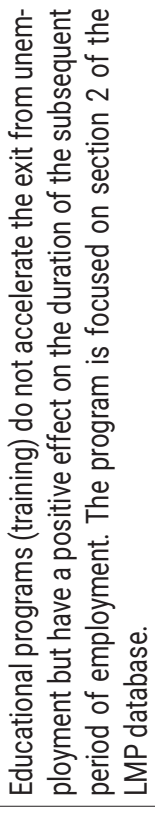 & 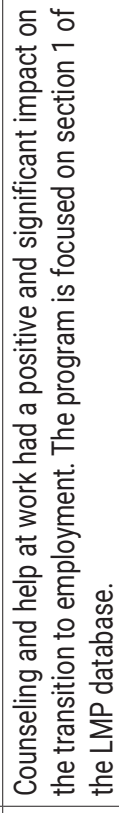 & 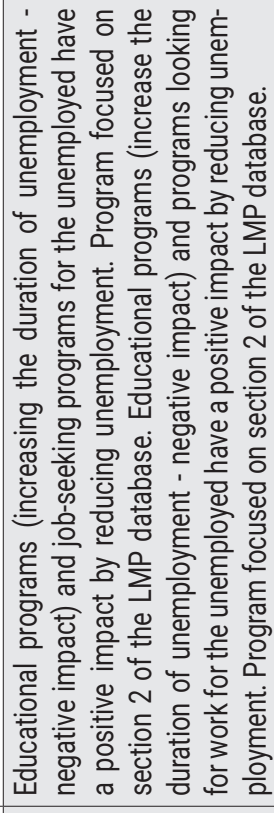 & 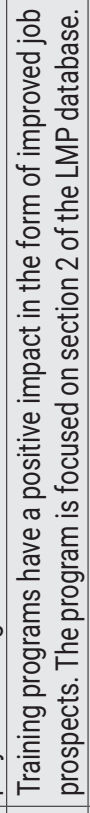 & 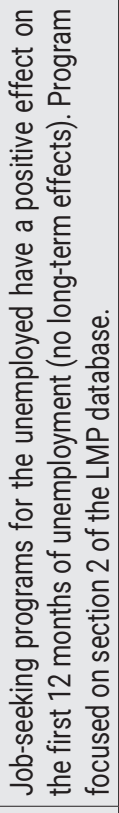 & 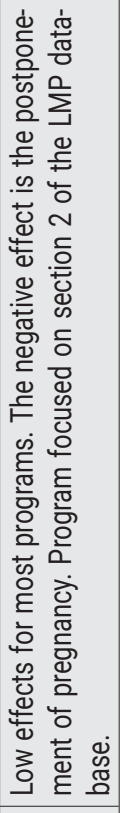 \\
\hline 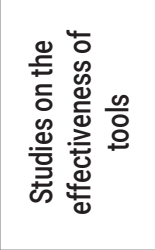 & 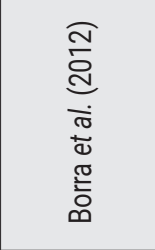 & 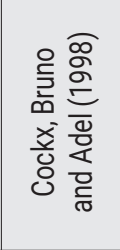 & 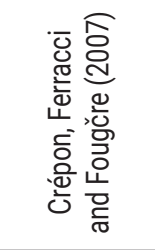 & 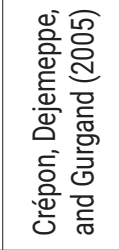 & 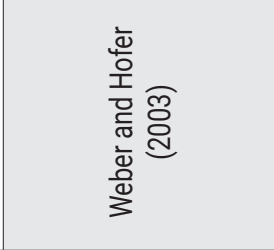 & 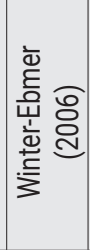 & 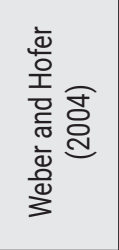 & 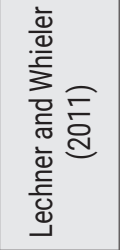 \\
\hline 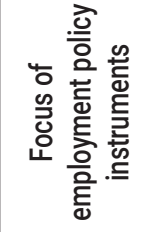 & 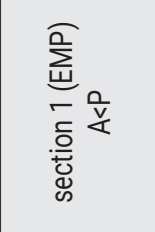 & & 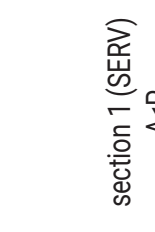 & & & 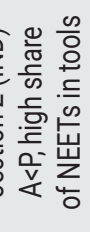 & & \\
\hline 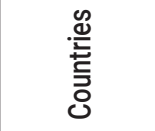 & \multicolumn{2}{|c|}{$\begin{array}{l}\text { क्ष } \\
\text { के }\end{array}$} & \multicolumn{2}{|l|}{ 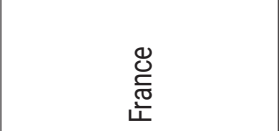 } & \multicolumn{4}{|c|}{$\begin{array}{l}\text { 竞 } \\
\frac{\text { 党 }}{4}\end{array}$} \\
\hline
\end{tabular}




\begin{tabular}{|c|c|c|c|c|c|c|c|c|c|}
\hline 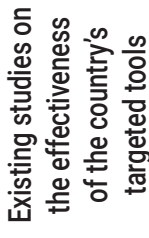 & 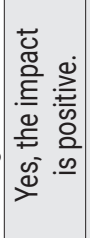 & 은 & 은 & 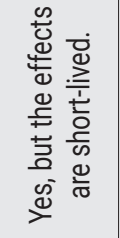 & 은 & 은 & 은 & 은 & 은 \\
\hline 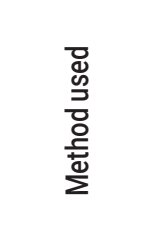 & 음 & 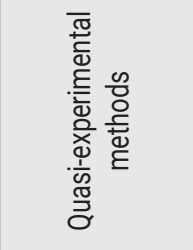 & 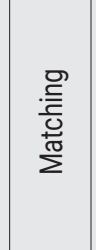 & 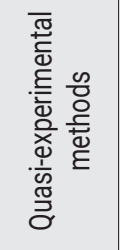 & 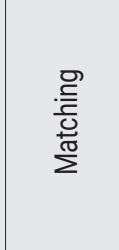 & 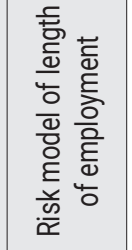 & 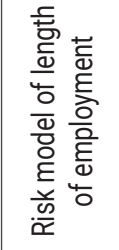 & 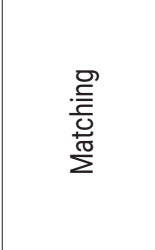 & 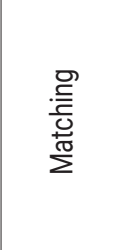 \\
\hline 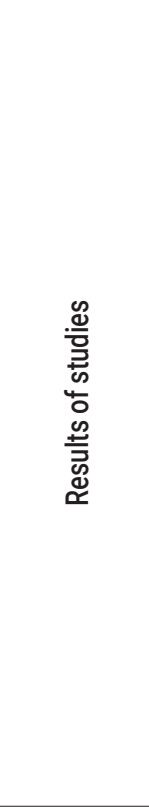 & 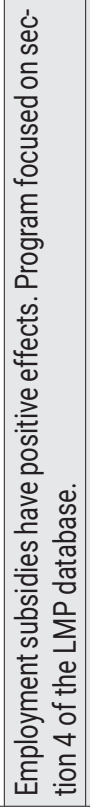 & 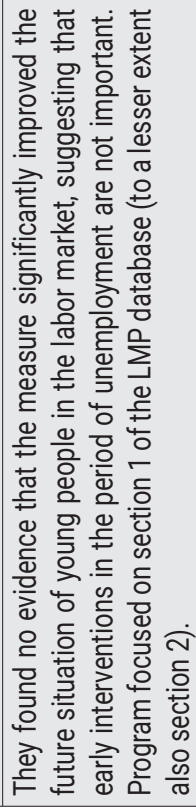 & 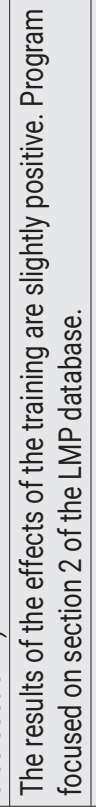 & 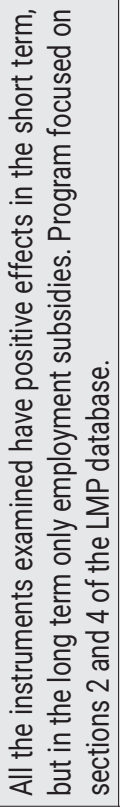 & 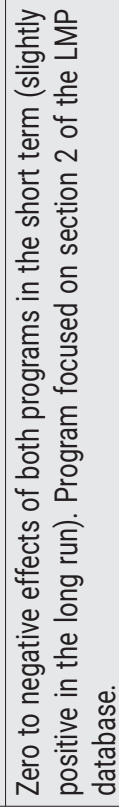 & 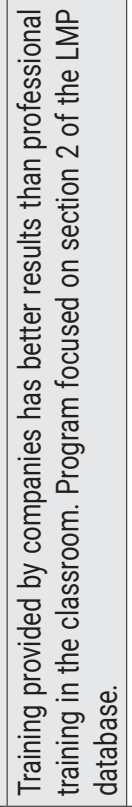 & 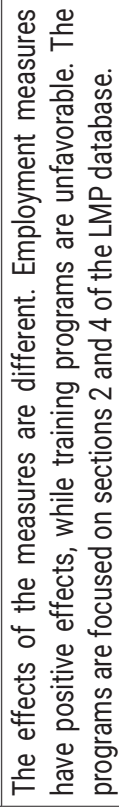 & 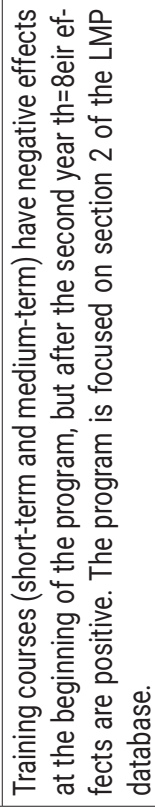 & 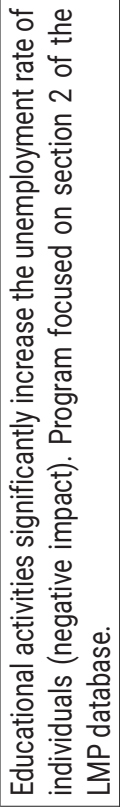 \\
\hline 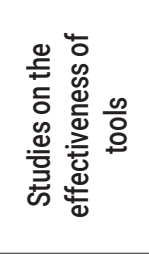 & 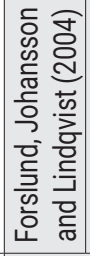 & 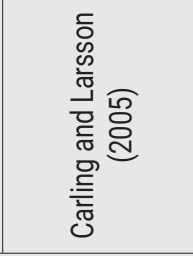 & 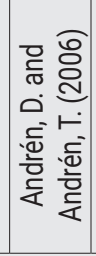 & 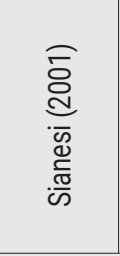 & 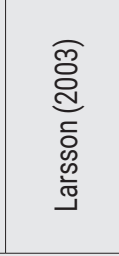 & 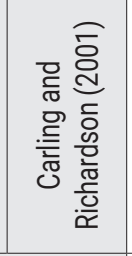 & 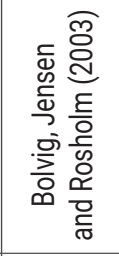 & 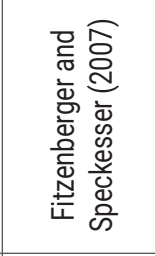 & 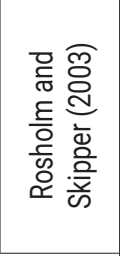 \\
\hline 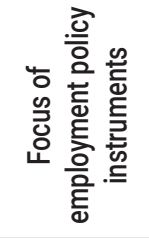 & \multicolumn{6}{|c|}{ 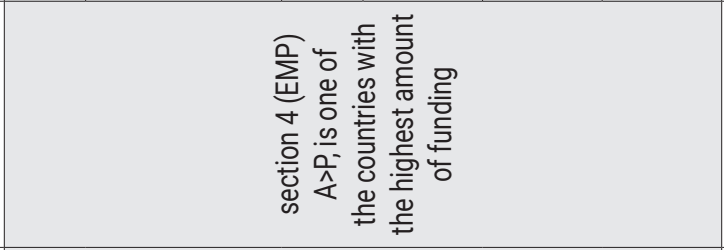 } & 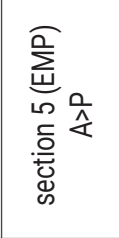 & & \\
\hline 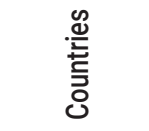 & \multicolumn{6}{|c|}{ 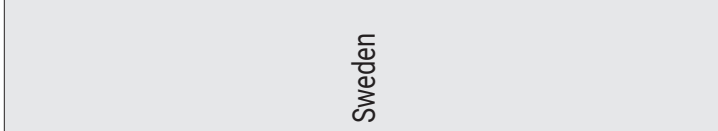 } & \multicolumn{3}{|c|}{ 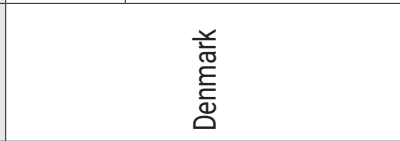 } \\
\hline
\end{tabular}




\begin{tabular}{|c|c|c|c|c|c|c|c|}
\hline 을 & 울 & 울 & 2ㅇ & 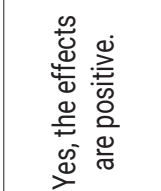 & 은 & 은 & 은 \\
\hline $\begin{array}{l}\bar{\partial} \\
\text { 들 } \\
\stackrel{ \pm}{ \pm} \\
\geq\end{array}$ & $\begin{array}{l}\stackrel{0}{0} \\
\sum_{\text {¿ }}\end{array}$ & $\begin{array}{l}\sum_{\sum} \\
\sum_{\infty}^{-} \\
\sum_{0}^{-}\end{array}$ & 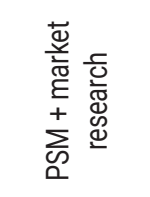 & 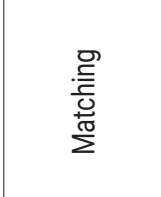 & 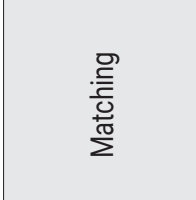 & $\sum_{\infty}$ & $\begin{array}{l}\text { 음 } \\
\text { ऐo } \\
\text { ¿ }\end{array}$ \\
\hline 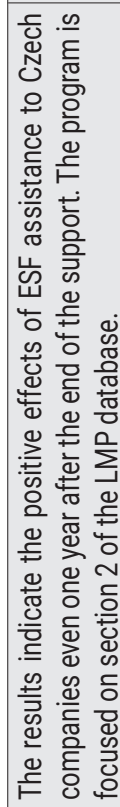 & 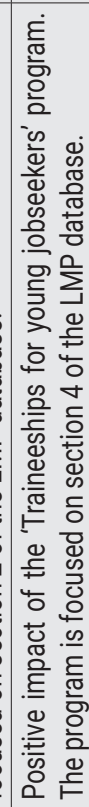 & 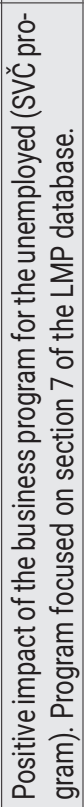 & 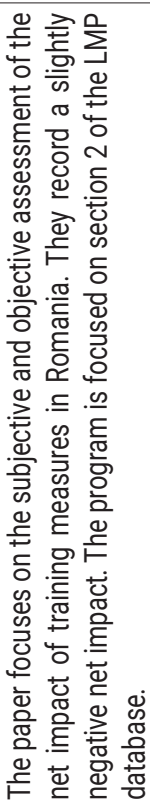 & 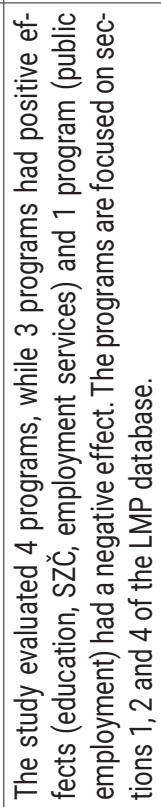 & 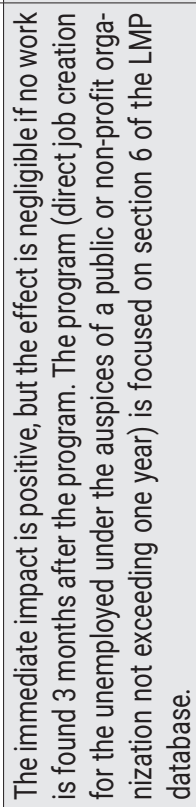 & 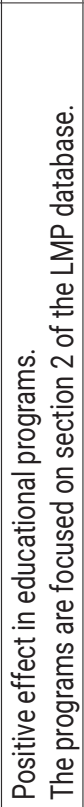 & 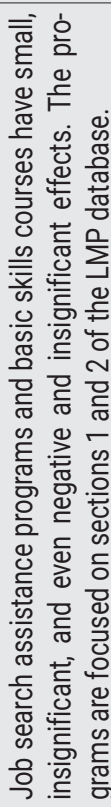 \\
\hline 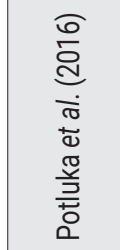 & 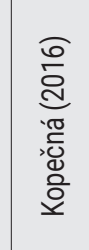 & 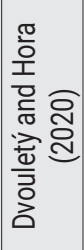 & 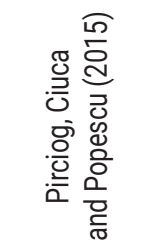 & 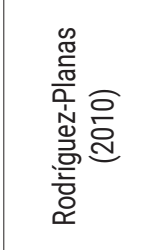 & 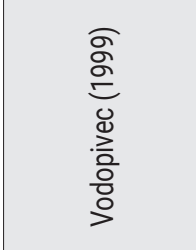 & 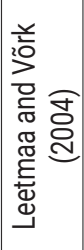 & 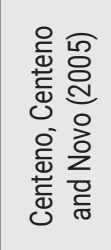 \\
\hline \multicolumn{3}{|c|}{ 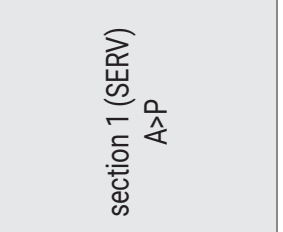 } & \multicolumn{2}{|c|}{ 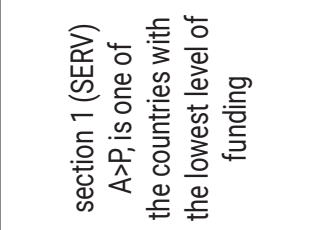 } & 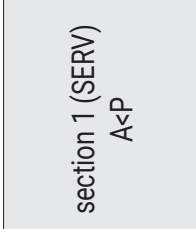 & 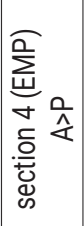 & 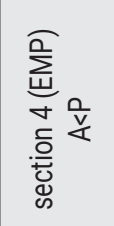 \\
\hline \multicolumn{3}{|c|}{ 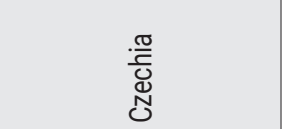 } & \multicolumn{2}{|c|}{ 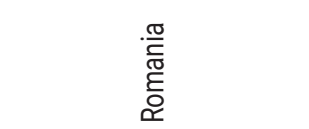 } & $\frac{\text { वे }}{\text { के }}$ & 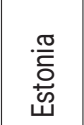 & 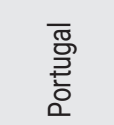 \\
\hline
\end{tabular}




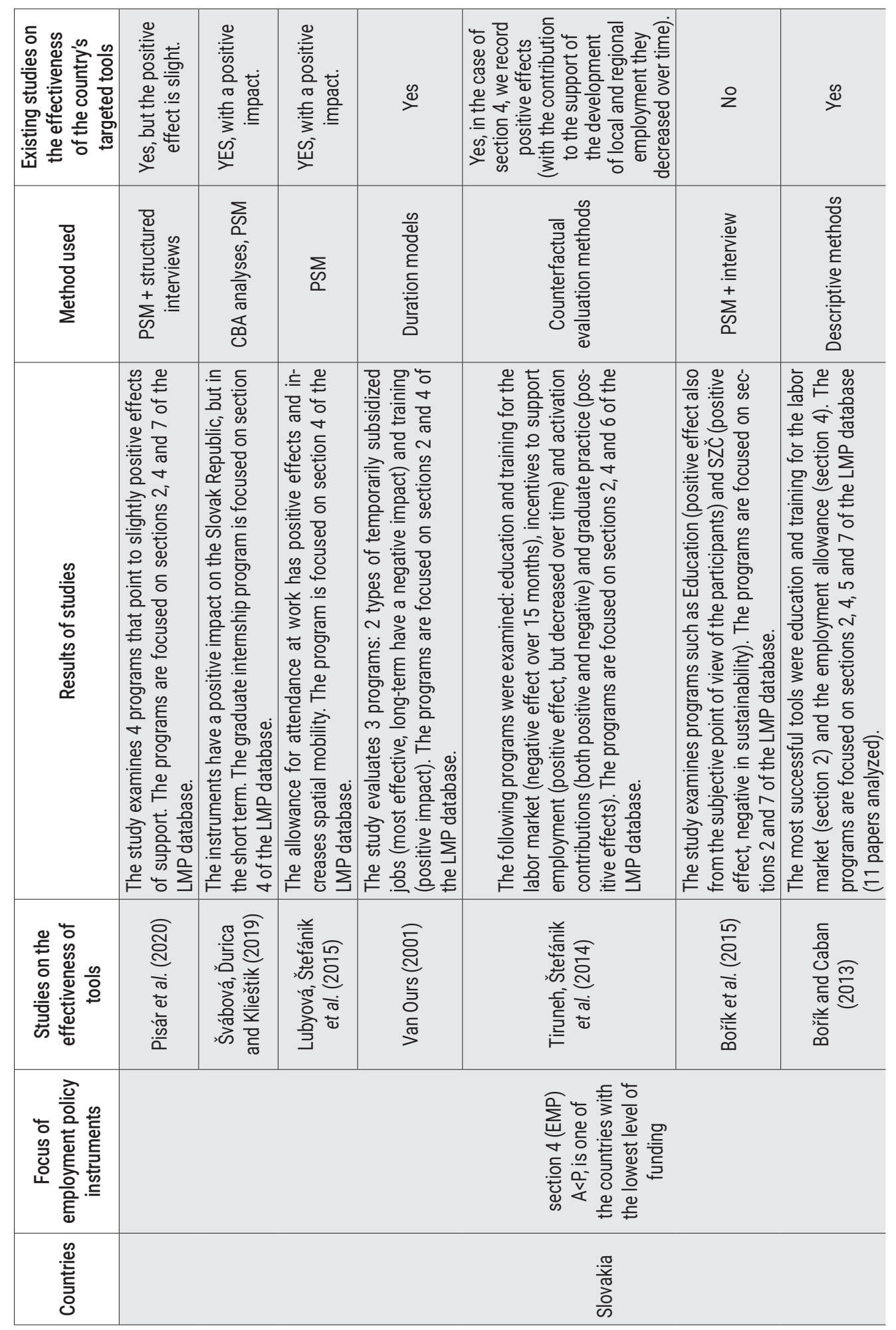




\begin{tabular}{|c|c|c|c|c|c|c|c|c|c|}
\hline 은 & 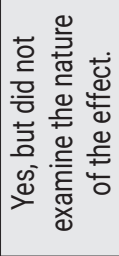 & 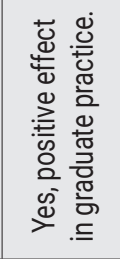 & 2ㅇ & 을 & 은 & $\times$ & $\times$ & & 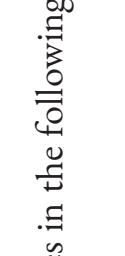 \\
\hline 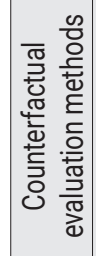 & 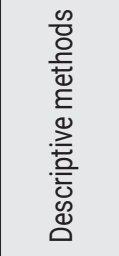 & 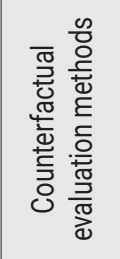 & 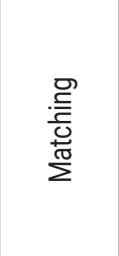 & 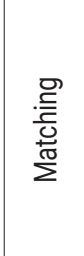 & 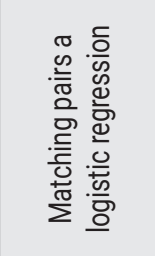 & 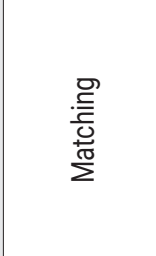 & 吝 & & 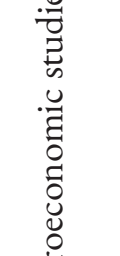 \\
\hline 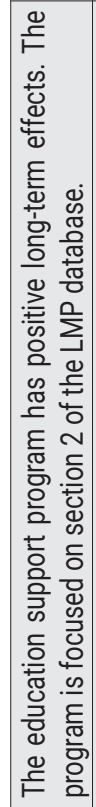 & 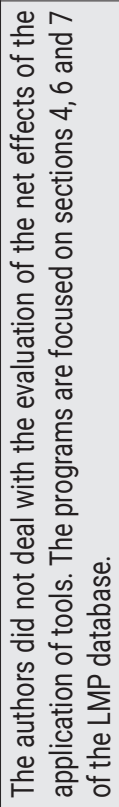 & 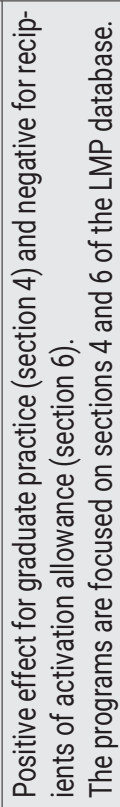 & 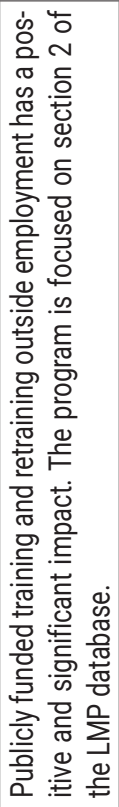 & 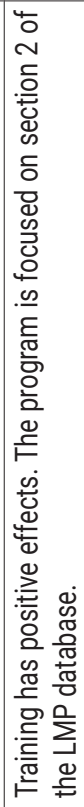 & 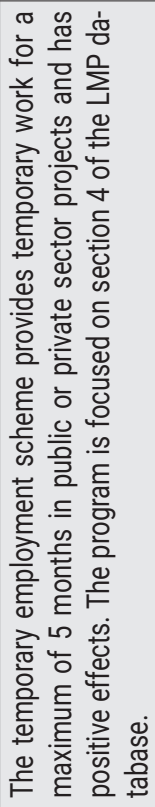 & 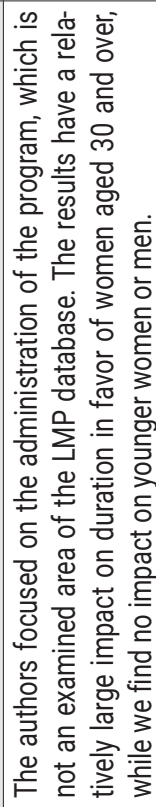 & 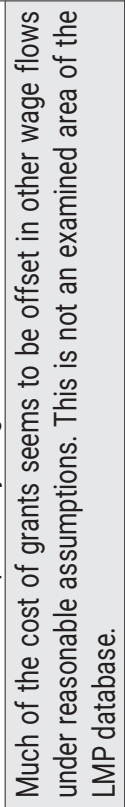 & & 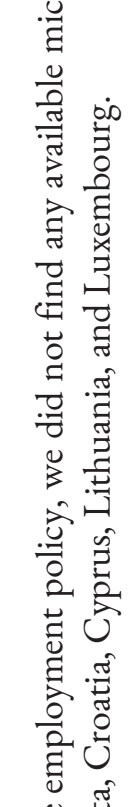 \\
\hline \multirow[t]{3}{*}{ 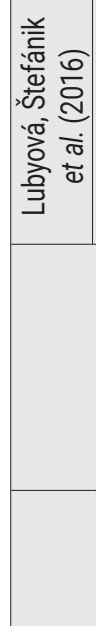 } & 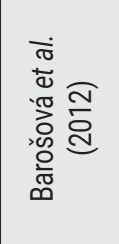 & 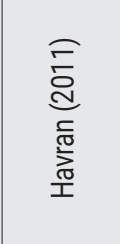 & 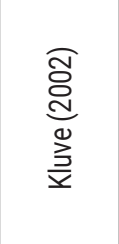 & 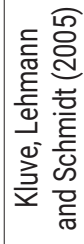 & 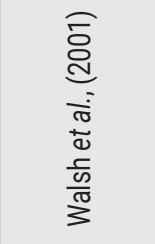 & 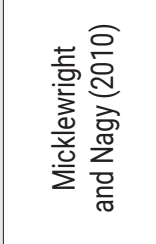 & 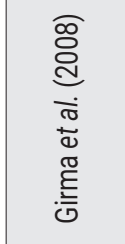 & & 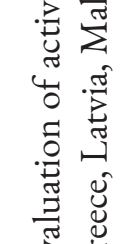 \\
\hline & & & \multicolumn{2}{|c|}{ 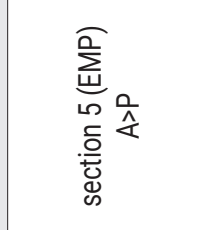 } & 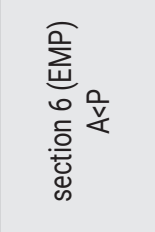 & 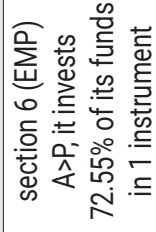 & 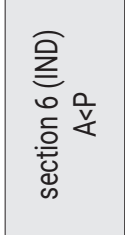 & & 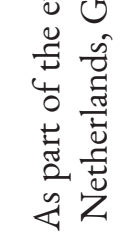 \\
\hline & & & \multicolumn{2}{|l|}{ 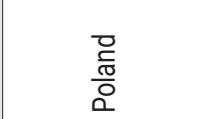 } & $\begin{array}{l}\overline{\bar{T}} \\
\text { o } \\
\overline{\bar{D}}\end{array}$ & $\begin{array}{l}\text { ㅁ } \\
\text { ড्工 }\end{array}$ & 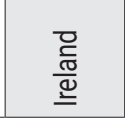 & & Zे \\
\hline
\end{tabular}

